Barttomiej Lis

Uniwersytet Wrocławski

\title{
Socjalizacja do normatywnej męskości: instytucje i mechanizmy kształtowania heterohabitusu. Przykłady ${ }^{1}$
}

Mężczyźni, którzy w dojrzałym życiu okażą się w dominującym stopniu homoseksualni oraz zidentyfikują się ze społecznie i kulturowo wyprodukowaną kategorią geja, w swym dzieciństwie i adolescencji nie są przedmiotem jakiejś innej niż zgodna z treściami dominującego przekazu na temat płci socjalizacji do męskiej roli. Geje, tak samo jak heteroseksualni, biseksualni czy wszyscy inni mężczyźni, w związku z pierwotną identyfikacją jako anatomiczni mężczyźni, są zgodnie z tą "obserwacją" wychowywani (rozpoczyna się performatywna procedura "umęskowiania” chłopięcego ciała, wyrabiania w nim właściwych zachowań, sposobów bycia - określona, czytelna płciowa dyspozycja zostaje uformowana). Pierwszym habitusem, przebijającym w późniejszych, ewentualnych „rekonstrukcjach", jest praktycznie zawsze habitus, w którego treść wpisana jest heteroseksualność jako immanentna część ludzkiej natury. Tropy przygotowywania chłopców do normatywnej męskości są również łatwo identyfikowalne w gejowskich narracjach na temat dzieciństwa i dorastania. Dominujące w dyskursie rozumienie męskości, w którym heteroseksualność jednostki jest bardzo ważnym elementem, było tematem socjalizacyjnych praktyk także $\mathrm{w}$ przypadku homoseksualnych mężczyzn (Levine 1998, s. 55). Gotowość do przyjęcia tej perspektywy przebiegała oczywiście z różnym skutkiem u każdego z gejów, z którymi rozmawiałem podczas swoich badań ${ }^{2}$, jednak mimo pewnych nielicznych „zwolnień" z normatywnego odgrywania płci najczęściej respondenci godzili się na tak zdefiniowaną swą społeczną/genderową rolę. Nie zawsze przebiegało to łatwo, śmiem twierdzić jednak, że podobne przykłady płciowego nonkonformizmu

\footnotetext{
1 Artykuł jest przekształconym podrozdziałem (fragmentem) mojej pracy doktorskiej zatytułowanej „Normy płciowe a strategie tożsamościowe gejów. Socjologiczna analiza tożsamości płciowej mężczyzn homoseksualnych", obronionej w 2013 roku na Uniwersytecie Wrocławskim.

2 Przygotowując doktorat, zbierałem narracje homoseksualnych mężczyzn (40 respondentów w wieku od 17 do 69 lat autodefiniujących się jako geje). Posługiwałem się przy tym metodą pogłębionych wywiadów o pewnym stopniu standaryzacji. Badanie realizowałem w dużych i średnich miastach w Polsce (Wrocław, Gdańsk, Warszawa, Bielsko-Biała) w latach 2008-2009.
} 
wytrawny badacz odszuka również w opowieściach wybranych heteroseksualnych mężczyzn.

W tym artykule przedstawię tylko niektóre mechanizmy kształtowania heteroseksualnego habitusu chłopców, skupiając się na instytucji grup rówieśniczych.

\section{Rówieśnicy: strażnicy genderu, stosunek do sfeminizowanej/nienormatywnej chłopięcości}

Opowieści mężczyzn homoseksualnych na temat ich dzieciństwa są bardzo zróżnicowane. Niektóre wypowiedzi doskonale wpisują się w tradycyjne wyobrażenie o chłopięcości, gdzie długie zabawy na świeżym powietrzu, gry zespołowe i inne typowe formy spędzania czasu wolnego mają "hartować” przyszłych mężczyzn. Są oczywiście również takie narracje, które z kolei ilustrują stereotypy o sfeminizowanych gejach. Wszystkie one mają w sobie ślady normatywnego działania otoczenia: gdy jednostka opowiada o zwyczajnym, tradycyjnym dzieciństwie i pozytywnie mówi o swoim w nim funkcjonowaniu, znak to, że podjęte socjalizacyjne działania trafiły na chłopca z wewnętrznymi predyspozycjami nieskonfliktowanymi z treścią tych praktyk. Jeśli zaś podmiot opowiada o trudnościach dorastania i mierzenia się ze słownymi szykanami, nieakceptującego jego niestandardowego zachowania otoczenia, jest to sygnał dla badacza, że za chwilę dowie się wprost o procedurach wymuszania tejże normatywności. W obu przypadkach aktywność rówieśników (chłopców przede wszystkim) na polu wytwarzania w jednostce właściwego rozumienia płci (bez względu na ile udanie jest ono potem replikowane/referowane) jest bezsprzeczna.

Podczas wywiadów zebrałem wiele świadectw „normalnego”, „podwórkowego" wychowania, w którym to respondent w żadnym stopniu nie był przedmiotem „normatywnego upomnienia” ze strony kolegów czy koleżanek (wyrażonego expressis verbis, bo „normatywne wezwania” oczywiście odbywały się wówczas w tle). Ciekawsze z punktu widzenia analizy praktyk normatywizujących w odniesieniu do płci są jednak te przypadki, gdzie jednostki w jakimś sensie odstawały od oczekiwanego stylu chłopięcości³. Inne dzieci (starsze i młodsze), a zwłaszcza chłopcy, są szczególnie aktywni na polu strzeżenia zasad płciowej poprawności ${ }^{4}$. Możemy być pewni, że nienormatywność w tym obszarze będzie

3 Oczywiście ta nieumiejętność/trudność w reprodukowaniu męskości tak samo może dotyczyć mężczyzn, którzy dzisiaj są $\mathrm{w}$ dominującej mierze heteroseksualni. Spodziewam się, że podobne badanie na tej grupie osób mogłoby przynieść odpowiednie dane, choć niewykluczone, że w związku z takim a nie innym statusem "sfeminizowanej chłopięcości" trudniej byłoby takie retrospektywne opowieści uzyskać (w obawie o odbiór przez badacza).

4 Badaczka społeczna Emma Renold odnotowała w swoich badaniach realizowanych w grupie uczniów i uczennic jednej z brytyjskich szkół podstawowych, że zachowania nieprzychylne „zniewieściałym” chłopcom występują również u niektórych dziewcząt. Jest to ta grupa, którą językiem Raewyn Connell nazwalibyśmy dziewczęcością emfatyczną/podporządkowaną, uznającą zasady patriarchalnej większości, w tym normy hegemonicznej męskości (Renold 2002, s. 424). 
z pewnością dostrzeżona i odpowiednio skategoryzowana. Dzieje się tak albo w związku z kulturową koniecznością naznaczenia jednostki odstającej od usankcjonowanej przez statystykę normy, wykluczenia poza dominującą grupę „właściwych postaw”, albo ukarania nonkonformizmu i/lub symbolicznego upomnienia się o „swojego", który ma odwagę zachowywać się niestandardowo, inaczej niż nakazuje tego męska/chłopięca rola (nadzorujące "płciową czystość" praktyki, których wykonawcami są normatywni chłopcy, dotyczą przede wszystkim osób tej samej co oni płci). Asortyment możliwych narzędzi, za pomocą których negatywnie sankcjonuje się niestandardowe zachowania niektórych chłopców, jest bardzo zróżnicowany. Najczęstszymi metodami są „śmiech” oraz „wyzwanie”, zaś niemal zawsze podstawą/bazą tych przemocowych działań jest jakkolwiek rozumiana domniemana kobiecość/zniewieścienie jednostki. Wśród określeń, którymi opisywano w dzieciństwie niektórych z moich respondentów, są między innymi następujące słowa: baba, babiarz, babski król, panienka, laluś, ciota, babochłop, maminsynek, pedał lub mięczak. Skojarzenia z kobiecością, niemęskością były najczęstszym sposobem językowego ukarania jednostki. Symboliczne odebranie męskości, zrównanie z "gorszą płcią" miało być z jednej strony sankcją korygującą niewłaściwe zachowania „kolegi”, a z drugiej sposobem na odcięcie się od jego nienormatywnego zachowania zgodnie z zasadą "pedalskiego dyskursu", o którym pisała socjolożka C.J. Pascoe ${ }^{5}$.

W szkole średniej, w pierwszych dwóch klasach przede wszystkim. Była taka jedna klasa, która strasznie mnie nie lubiła, mimo że mnie oczywiście nie znała, i chodzili za mną przede wszystkim chłopacy z tej klasy i wołali mnie po imieniu, tak zdrobniale "Michałek, Michałek", potem oczywiście padało w eter słowo „ciota”. Biegali za mną po szkole i tak wołali. Oczywiście strasznie mnie to denerwowało i zawsze puszczałem im wiązankę przekleństw, natomiast nic nie mogłem na to poradzić. Natomiast, jak się później okazało jeden z tych ludzi, z tej klasy, jest gejem. (...) Nie wiem co było tego przyczyną. Być może to, że przebywałem z dziewczynami, być może to, że byłem aktywistą w szkole, być może jakiś mój sposób bycia, który się właśnie uwidocznił, któreś z moich niekontrolowanych zachowań, sposób gestykulacji, głośnego mówienia, bo ja zawsze głośno mówię jak się ekscytuję, a to przede wszystkim chyba jest mało męska moja cecha. To może właśnie te cechy spowodowały (Michał, 23).

Michał, starając się wyjaśnić, czym były spowodowane nieprzyjemne dla niego wyzwiska, trafnie rozpoznaje w swoich zachowaniach takie elementy, które - jeśli zostaną dostrzeżone - zwykle są przez pewne grupy kojarzone

5 Młodzież, zdaniem Pascoe, sięga po określenia typu „pedał"/"ciota" niekoniecznie z zamiarem obrażenia chłopca, który rzeczywiście ma ku takiej seksualności inklinacje, lecz raczej, by zdyscyplinować innych młodych mężczyzn i przestrzec ich przed niemęskimi (czyli kobiecymi $\mathrm{w}$ oczach większości) aktami. Ciągłe używanie homofobicznego słownictwa w kulturach młodzieżowych ( $w$ tym przede wszystkim przez chłopców) pełni więcej funkcji aniżeli tylko stygmatyzowanie i wykluczanie nienormatywnych seksualności. „Pedalski dyskurs” (fag discourse), jak go nazywa socjolożka, jest stale odtwarzającą się opowieścią, której użycie przez podmiot, choćby na moment, stabilizuje jego chwiejną męską tożsamość. Osiągnięcie tego stanu jest możliwe tylko kosztem odebrania męskości innym (symbolicznie dokonuje się to poprzez nazwanie drugiego "pedałem”) (por. Pascoe 2005, 2007). 
z niemęskością, zniewieścieniem. Zdrobniałe tytułowanie chłopaka ma symbolicznie go „udziecięcać”. Jest to jeden ze sposobów odbierania męskości. Zwraca również uwagę fakt, że wśród opresorów znajdują się jednostki nieheteroseksualne, które w wyższym stopniu opanowały normatywny sylabus. Dowodzi to raz jeszcze tego, że seksualność niekoniecznie musi być powiązana z genderem, oraz że homofobiczne zachowania oddalają od podmiotu podejrzenie o ich własny homoseksualizm, ergo - niemęskość.

Przemek opowiedział mi o trudnych relacjach, jakie miał z męską częścią swojej gimnazjalnej klasy:

(...) zaczynały się robić już takie starcia, zwłaszcza w gimnazjum, pomiędzy mną a tymi hetero-kolegami, którzy właśnie lubią grać w piłkę nożną, trzymają się zawsze razem, którzy lubią takie "typowo" męskie, oczywiście w cudzysłowie, rozrywki. Pojawiały się jakieś prostackie teksty... no. Ogólnie przez całe gimnazjum, oni już na początku, ubzdurali sobie, że jestem gejem, nawet ja nie wiedziałem tego dokładnie, nigdy nie padło to $z$ moich ust, nawet tego nie zasugerowałem. Ale oni tak sobie to po prostu ubzdurali, zawsze było wiadomo, że ja jestem gejem i tak już było przez całe gimnazjum. To nie był oczywiście "gej” to zawsze był "pedał”... tak właśnie to wyglądało. Oni byli bardzo heteroseksualni, cały czas rzucali jakimiś tekstami z pornosów. Zresztą możesz sobie wyobrazić: banda gości, którzy próbują być tacy czadowi... no a dla mnie byli żałośni i wciąż są (Przemek, 20).

Historia ta jest przykładem, jak pewne zachowania, zwyczaje, nawyki (w tym konkretnym przypadku było to preferowanie towarzystwa dziewcząt oraz niechęć do zajęć sportowych) mające dowodzić, że chłopiec nie do końca akceptuje zasady normatywnej męskości, łączone są automatycznie z homoseksualnością. Respondent jeszcze do końca sam nie wiedział, czy jest gejem, można powiedzieć, że powiedziano mu o tym, bazując jedynie na pewnym zbiorze stereotypowych cech. W dalszej części mój rozmówca włącza przymiotnik „heteroseksualny” do opisu „męskości” i zachowań swoich adwersarzy. Także dla niego nie jest żadnym zaskoczeniem, że częścią tradycyjnie rozumianej hegemonicznej męskości jest heteroseksualność.

W podobnym duchu utrzymana jest inna relacja. Mateusz bardzo wcześnie zinterpretował swoje pragnienia seksualne jako $\mathrm{w}$ dominującym stopniu homoerotyczne. Dokonał coming outu, nie kryjąc się tym z otoczeniem. Wiadomość ta skutkowała szeregiem agresywnych zachowań, dla których podstawą była homofobia i założenie o sprzeniewierzaniu się homoseksualnego mężczyzny idei męskości (męskość jako heteroseksualność) (Redman 2000, s. 488).

Byłem bardzo cichy, spokojny, uczyłem się i nadal uczę bo lubię to, no i uprawiano nade mną mobbing, więc nie miałem zbyt dużo przyjaciół. Do tego dochodziło to, że otwarcie byłem gejem - co było masakryczne. W czasach szkoły byłem bity, wyzywany, nie miałem zbyt wielu przyjaciół - bardziej siedziałem na Internecie albo czytałem książki. Jak mnie pobito, wylądowałem w szpitalu. Pamiętam do dzisiaj, powiedziano mi: „Po co masz chuja? Chuj jest do tego żeby wkładać. Chuja masz po to żeby go wkładać, a nie po to żeby nim się bawić bądź robić laski innymi" (Mateusz, 17). 
Opresorzy powołują się na wyobrażenie o aktywności, dominacji, insertywności w trakcie stosunków seksualnych jako męskich atrybutach. Każde inne, nawet wyobrażone, (nie)użycie męskiego organu rozrodczego jest traktowane jako niewłaściwe, niegodne mężczyzny. Wiedza o homoseksualności Mateusza pozwalała go w ich oczach feminizować, to zaś wtórnie miało stanowić usprawiedliwienie dla przemocy wobec niego stosowanej (Barron, Bradford 2007, s. 242). Wulgarne pytania, które zadano chłopcu, są też symbolicznym upominaniem się o "swojego" i domaganiem się jednoznaczności świata, tego by był on przejrzysty i czytelny. Taka sytuacja jak homoseksualność ich rówieśnika zasiewa niepokój i może zachwiać wyznawanym systemem organizacji płci i seksualności.

„Seksualne narzędzia” jako sposób na poniżenie nienormatywnie zachowującego się chłopca stosowali również „koledzy” Jarka. Wszystko co go kwalifikowało do bycia ofiarą przemocy to fakt, że lubił muzykę Madonny, kolegował się z dziewczynami, był dobrym uczniem i był otyły.

Bardzo wielu chłopców robiło coś takiego w podstawówce, że na przykład ściągało gacie i zasłaniało sobie dłonią... Nie tylko w stosunku do mnie, ale był taki trend i ja również... Wobec mnie również takie rzeczy robili, że na przykład ściągali gatki i wystawiali sobie „interesy” na zewnątrz, ale te „interesy” zakrywali dłonią no i udawali kopulację... I mówili na przykład, żeby brać do buzi czy żeby „bakać“ (w młodzieżowym slangu znaczy tyle co uprawiać seks oralny - BL), (Jarek, 26).

Symboliczne zdegradowanie słabszego, w ich oczach niemęskiego, chłopca przyjmuje formę figuratywnego podporządkowania, wpisania $\mathrm{w}$ pasywną seksualną rolę, funkcjonalnego uprzedmiotowienia odmieńca - skoro jest w jakimś sensie zniewieściały, zatem pokażmy mu jego miejsce w genderowym/seksualnym porządku (por. Lis 2010, s. 145-146).

Jeden z respondentów zwraca uwagę, że „korekcyjne działania” (forma kary za swoiście rozumianą płciową nienormatywność) najczęściej są działaniami grupowymi. Jest to rytuał, który ma sens w momencie, gdy odgrywany jest przed „publicznością". Zwiększona widownia sprawia również, że więcej osób chce lub czuje się zobligowanych do włączenia się w tego typu praktyki. Zgodnie z filozofią "pedalskiego dyskursu” w opresjonujących zabiegach jest tyle samo negatywnego sankcjonowania niemęskości w anatomicznym mężczyźnie co prewencji: pokazania innym, że jest się męskim (a dzieje się to również poprzez odebranie męskości innym).

Pamiętam, że miałem przezwisko „Laluś”, to długo było. „Panienka” tak samo. To wynikało z zachowania, ze stylu bycia. (...) To zawsze były takie zachowania, grupy wobec mnie, a nigdy indywidualnych osób. Nikt indywidualnie ze mną nie rozmawiał, że coś mu we mnie nie pasuje, zawsze było ok, dopiero jak się zebrali grupą, wtedy coś próbowali działać (Filip, 20).

Niektórzy z moich rozmówców, opowiadając o okresie dzieciństwa, dojrzewania, wspominali, że łatwiej nawiązywali kontakty z dziewczynkami niż z innymi chłopcami. Zwracali uwagę, że kontakty te charakteryzował mniejszy poziom 
rywalizacji, swoboda, brak konieczności udowodnienia czegoś. Również niechęć do jednego z konstytuujących "chłopięcą męskość” elementów: bójki wewnątrz własnej grupy płciowej oraz zaczepianie dziewcząt, często towarzyszyła tym respondentom (por. Epstein 2006).

Jeśli chodzi o kolegów to w większości to były koleżanki (śmiech - BL), nie miałem zbyt wielu kolegów. Nie preferowałem takich męskich zabaw. Jak mówi moja mama: „zawsze wolałeś zbierać kwiatki, bawić się z babcią, zamiast się bawić w wojnę z kolegami". Także bardziej na takich dziewczyńskich zabawach mi to dzieciństwo upłynęło, bardziej to mi się podobało, może też dlatego, że wychowałem się wśród dominujących kobiet, bo wokół mnie było wiele kobiet, z mężczyzn to był tylko tata, jakiś tam wujek i dziadkowie, a tak same kuzynki, siostra, mama, babcie. (...) Bardzo lubiłem się bawić w sklep, w dom, z kolegami w sumie nigdy jakiegoś kontaktu nie miałem. Chłopcy byli gdzieś tam, ale ja z koleżankami mieliśmy swój świat. Nigdy nie angażowałem się w jakieś typowe męskie zabawy, jak np. piłka nożna, której nie znoszę, nienawidzę jej. Chłopacy w przedszkolu byli zawsze przyzwyczajeni, że ja trzymam z dziewczynami i robimy swoje rzeczy, a oni swoje, po prostu nie wchodziliśmy sobie w drogę. To było z góry ustalone, to był podział ról: ja robię swoje, oni robią swoje, oni biegają po boisku, my tam sobie byliśmy na jakiejś łączce, nie było z tym żadnego problemu. To się zmieniło dopiero w gimnazjum (Przemek, 20).

Ja pamiętam, że ... właśnie odkąd pamiętam to lubiłem się bawić z dziewczynami. Miałem całą masę przyjaciółek, znajomych, koleżanek. Z chłopcami to tak nie bardzo, wkurzali mnie strasznie, oni gdzieś latali, mieli jakieś durne zabawy, typu strzelanie. Mnie to zupełnie nie interesowało, ale to jakoś całkiem naturalnie wychodziło - wspólny język, i jak się jakieś przyjaźnie zawiązywały to to zawsze były dziewczyny, nawet nie wiem jak to się działo. Mam jeszcze starszą o rok siostrę, to jest bardzo podobny wiek, ona też miała wokół siebie same koleżanki, więc wokół było więcej dziewczynek niż chłopców. One często jakiś kocyk przynosiły, wykładały na trawniku, wyciągały lalki - ja zawsze w tym uczestniczyłem. W gumę się grało, w klasy, coś w tym stylu. Oczywiście chłopcy bardzo szybko zaczęli rzucać takimi wyzwiskami w stylu „babiarz", no i takie historie (Kuba, 27).

Zarówno Kuba, jak i Przemek, odpowiadając na pytanie o dziecięce znajomości i zabawy, potwierdzają stereotyp geja znajdującego swoje miejsce w centrum „babińca”, oczywiście opowieść ta nie jest reprezentatywna dla wszystkich homoseksualnych mężczyzn, o czym za chwilę. W tym miejscu chciałbym jedynie zwrócić uwagę, że rozmówcy mówili o tym z uśmiechem, wyczuwalny był dyskretny wstyd. Zażenowanie sytuacją, że nigdy nie mieli „męskich” (czytaj: heteroseksualnych) przyjaciół, a tym samym ich przyjaźnie nie są tymi prawdziwymi? Odnosi się to do archetypu męskiej przyjaźni, chłopięcych zabaw, baśniowej „Nibylandii" z prozy Jamesa Matthew Barrie'go. Socjolog Dwight Fee na podstawie swoich badań doszedł do wniosku, że dla wielu homoseksualnych mężczyzn przyjaźń z innymi mężczyznami (zwłaszcza jeśli są heteroseksualni) jest czymś pożądanym, i możliwe, że przez fakt jej rzadszego doświadczania bardziej wartościowym (Fee 2000, s. 57-58). Z pewnością zaś jest bezpieczniejsza jeśli chodzi o ocenę rówieśników, co potwierdza Patryk: 
Zawsze gdzieś mnie bolało, że w liceum... bo w podstawówce to jeszcze z dziewczynami i chłopakami, a w liceum to już tylko ciągle trzymałem się z dziewczynami i to mnie właśnie bolało, bo wtedy jeszcze się bardzo liczyłem z opinią co ludzie powiedzą. Bolało mnie, że ja nie mam kontaktu z tymi chłopakami, że oni trzymają się razem, a ja nie jestem $z$ nimi i jak ja jestem odbierany? Że ja jestem inny, i wiadomo od razu wszyscy coś sobie pewnie myślą - „co jest z nim nie tak?". I to było dla mnie jakąś traumą (Patryk, 24).

Otaczanie się samymi dziewczynkami w okresie przedszkolnym i wczesnoszkolnym może być podstawą do zakwestionowania „chłopięcości” chłopca, tak samo jak niewykluczone jest, że późniejszy brak żeńskiego towarzystwa (w okresie już dojrzałym) może skutkować suponowaniem homoseksualności mężczyzny. Patryk wyczuwał tę presję i uznawał wagę posiadania „męskich” przyjaciół. Kulturowo taki rodzaj znajomości jest mitologizowany i przedstawiany jako bardziej atrakcyjny społecznie (przynoszący wymierne korzyści) aniżeli przyjaźn $\mathrm{z}$ kobietą.

Łatwość w kontaktach z dziewczynkami, o której opowiadali wyżej cytowani młodsi rozmówcy, nie musiała wcale być tak prosta dwie czy trzy dekady wcześniej. Jak opowiada Irek, już nawet sam pomysł, próba zrealizowania takiej znajomości była wewnętrznie hamowana. Respondent nawet nie mógł się przekonać, jakie konsekwencje dla jego społecznego funkcjonowania w grupie rówieśniczej mogłyby przynieść dziewczęce znajomości.

Ja miałem owszem jakieś takie bliższe kontakty, lepiej mi się rozmawiało z dziewczynami, ale wtedy to było tak, że w tym wieku koleżanka odpada. Mieć koleżankę, to jest nie do zaakceptowania, bo to od razu zostanie przekształcone na prawda "kochają się wielce" albo coś w tym rodzaju. Że para. Więc to rzeczywiście był taki etap, gdzie owszem, mi się jakoś tam w miarę rozmawiało, ale to nie tak, żebym ja zadzierzgnął jakąś taką poważniejszą relację. To dopiero w liceum tak się zaczęło dziać, że ja zacząłem mieć rzeczywiście przyjaciółki. Natomiast w podstawowej, to nie. To myślę, że jednak presja taka grupowa, typu że chłopaki z chłopakami, dziewczyny z dziewczynami, to ona była wystarczająco silna, żebym ja też tego nie zaakceptował (Irek, 45).

W wypowiedziach starszych respondentów dostrzec można nie tylko, że presja otoczenia skutecznie blokowała podjęcie jakichkolwiek działań, które mogłyby naruszyć "chłopięcą reputację", ale również to, że owa praktykowana niechęć do dziewcząt była w pełni zinternalizowana, zaś wykluczenie ich ze swojego towarzystwa tłumaczono osobistymi predyspozycjami. Leszek mówi:

Nie bawiłem się nigdy lalkami, ani nie bawiłem się z dziewczynkami w jakiś dom... nie grałem też $\mathrm{w}$ gumę. Raz mnie postawiły $\mathrm{w}$ tej grze i byłem $\mathrm{z}$ tego powodu bardzo nieszczęśliwy, bo uważałem że to strasznie niemęska gra. Myślałem „matko boska, co ja tutaj robię z tymi babami?". Miałem jakąś taką podświadomą niechęć do kobiet. Chciałem być dobrym kolegą, więc wytrzymałem to granie w gumę, ale nie sprawiało mi to żadnej satysfakcji. Co prawda piłka też nie sprawiała mi żadnej satysfakcji, ale z tym można się było już bardziej pogodzić, bo to już była męska gra. Grali w nią chłopcy, natomiast w gumę skakały głównie dziewczynki i to było absolutnie nie do zaakceptowania (Leszek, 44). 
Dla niektórych respondentów ich dopiero kiełkująca seksualna nienormatywność, która mogła, choć nie musiała, być zauważona i stereotypowo łączona z przeciwną płcią (trzymając się cały czas binarnego jej rozumienia), nakładała się na inny, bardziej widoczny i „skandaliczny” nonkonformizm. Dla Miłosza przynależność do subkultury gotyckiej wiązała się z dodatkowymi problemami z akceptacją przez otoczenie. W estetyce tych grup jest między innymi malowanie twarzy i farbowanie (długich) włosów przez mężczyzn, kolczykowanie ciała, buty na wysokich koturnach. Nie jest to związane z seksualnością członków subkultury.

To był chyba koniec podstawówki, taki okres prawie wakacyjny. Pamiętam, że ze znajomymi wyszliśmy w takich makijażach dosyć ostrych na ulicę i do szkoły, i ze szkoły. No i tak to się wtedy skończyło, że o mało nas nie pobili. Najpierw stwierdzili delikatnie, że tylko dziewczyny mogą się malować, kiedy ich olaliśmy, no to się zaczęła pyskówka. No taka typowa polska pyskówka: „o pedale jebany!”, itd. Pamiętam, że uciekliśmy wtedy i na tym się skończyło. No i w szkole były też takie trochę problemy. Może usunąć, może gdzieś przenieść, może psycholog by się przydał itd. (Miłosz, 25).

Narracja ta jest świadectwem na normatywne rozumienie ról płciowych, które jest dominujące w polskim społeczeństwie. Każda niesubordynacja w obszarze męskiej korporalności, stylizacji ciała jest niemal automatycznie wiązana z homoseksualnością, albo jako kwalifikująca się do konsultacji psychologicznej. Ludziom bardzo trudno jest poszerzyć swoje wyobrażenia na temat tego, jak bardzo można oddalić się od tradycyjnego modelu męskości i nadal społecznie funkcjonować jako mężczyzna.

\section{Nadwaga, nauka, sport}

Nie tylko jednoznaczne sfeminizowanie (delikatne ruchy, długo utrzymująca się mutacja, „niewłaściwy” ubiór, „dziewczęce” hobby czy po prostu nadreprezentacja dziewczynek wśród znajomych) dorastającego chłopca spotyka się z negatywną reakcją rówieśników. Także inne, pozornie bardziej neutralne, zachowania czy cechy osobowe mogą zostać nazwane „niemęskimi”, łamiącymi jakąś kulturową normę męskości. Tak jest na przykład z nadwagą, niechęcią do gier zespołowych albo osiąganiem dobrych wyników w nauce. Irek tak tłumaczy swoje szkolne wyobcowanie i problemy w kontaktach z rówieśnikami:

Wtedy to ja raczej przypisywałem to swojej nadwadze. Natomiast myślę, że to był zespół różnych rzeczy: gruby, nieruchawy, dobrze się uczy - kujon! To nie jest bardzo lubiany zespół. Nie dość, że on zawsze ma piątki i w związku z tym popatrz on się nauczył a ty baranie się nie nauczyłeś, prawda? To jeszcze wtedy na dodatek kiedy są takie zabawy typu społecznego, typu: razem pokopać piłkę, albo razem coś tam zrobić, które ludzi zbliżają, to ja w nich nie uczestniczyłem. Po prostu nie grałem. Ja chciałem porozmawiać, a oni chcieli co innego, po prostu kurde Irek był trochę inny, no i tyle (Irek, 45). 
Inny mój rozmówca podzielił się ze mną swoimi pytaniami o przyczyny agresji, z którą wielokrotnie stykał się w dzieciństwie.

Na przykład jeżeli można po mnie poznać, że jestem zakochany w jakieś dziewczynie, a mimo to jestem tym kozłem ofiarnym, no to znaczy, że nie było to związane z moją pojawiającą się $w$ tym czasie homoseksualnością, poza tym, zawsze wydawało mi się, że znałem chłopaków, także po stronie agresorów, którzy... tak podejrzewałem, wyczuwałem, że mogą być np. homoseksualni, albo mogą mieć inne powody do inności i oni odnajdywali się świetnie. Mogli być w grupie agresorów, albo być zupełnie poza tą przemocą (Tomek, 23).

Homoseksualność jako erotyczna preferencja (jeśli nierozpoznana/niewidoczna) nie musi być, jak widzimy, przyczyną rówieśniczego wykluczenia, tak samo jak nie „ratuje” od tego fakt zainteresowania dziewczynkami. Szykany konstruowane wokół tematu „niemęskości" niekoniecznie są prostą konsekwencją jakiegoś jednego przykładu chłopięcej nienormatywności. Nie jest regułą, że każdy otyły uczeń stanie się ofiarą szkolnej przemocy. Z pewnością o fakcie wykluczenia decyduje konfiguracja różnych czynników, wśród których nadwaga może być jednym z nich. Podobnie jak otyłość kojarzona jest z pasywnością, niemocą, miękkością, potencjalnością penetracji (Padva 2002, s. 281-292), tak też szkolna pilność i osiąganie dobrych wyników w nauce jest odczytywana przez niektóre młodzieżowe subkultury jako przejaw niemęskości. Debbie Epstein w swoich badaniach pokazała, że opór niektórych chłopców do zakończonego sukcesem uczestniczenia w procesie pedagogicznym związany jest nie tylko, jak twierdzą niektórzy, z pochodzeniem klasowym, lecz również ze specyficznym rozumieniem męskości. Praca szkolna, również przez fakt sfeminizowania kadry dydaktycznej, bywa interpretowana jako niemęska, a co za tym idzie - stanowiąca zagrożenie dla męskiego (heteroseksualnego) statusu ucznia. Respondenci - geje - z którymi w toku swoich badań rozmawiała brytyjska badaczka, często wskazywali, że fakt osiągania przez nich dobrych wyników w nauce był podstawą do szkolnej przemocy, w tym mowy nienawiści o homofobicznym charakterze (Epstein 2006, s. 289).

Analogicznie gorsze usportowienie, unikanie lekcji wychowania fizycznego może być pretekstem do wyzwisk czy też wyśmiewania. Naturalną przestrzenią, w której może i powinna kształtować się w chłopcu męskość, jest metaforyczne boisko do gry w piłkę. Powtarzająca się absencja na zajęciach sportowych lub niesatysfakcjonujące wyniki mają dowodzić niemęskości jednostki. Co ważne, miarą fizycznej sprawności, siły i męstwa jest uczestnictwo niemal wyłącznie w sportach zespołowych. Sukcesy w innych formach aktywności fizycznej, na przykład w pływaniu lub tańcu, niekoniecznie muszą oddalać podejrzenia o homoseksualizm (brak męskości).

Sport lubię uprawiany przeze mnie samego. Nie trawię piłki nożnej. Dwudziestu dwóch idiotów z piłką. Wolę pływanie, nie lubię nic z piłką praktycznie. Jak byłem mały, to postawiono mnie na bramce i oberwałem mocno w głowę. W szkole zawsze starałem się iść do lekarza i prosiłem, błagałem czasami, żeby mi wypisała zwolnienie na cały rok ze sportu. I byłem wtedy szczęśliwy. Ze strony reszty chłopaków miałbym 
nieprzyjemności gdybym był na sporcie. Wtedy by mnie piłką masakrowano, ja o tym wiedziałem, bo mi grożono. Starałem się opuszczać salę i sobie gdzieś siedzieć, byleby nie być na sali (Mateusz, 17).

Sport, jak to już zostało kilkakrotnie napisane, jest ważnym elementem w procesie kształtowania męskiej tożsamości. Zwłaszcza piłka nożna posiada olbrzymi kulturowy kapitał i symbolizuje „prawdziwą męskość” (Barron, Bradford 2007, s. 250). Tą drogą odbywa się płciowe różnicowanie - zaznaczanie odmienności od dziewcząt, a także subordynowanie alternatywnych („niemęskich”) wersji chłopięcości (Renold 2002, s. 283).

Paweł - inny respondent - czuł się wykluczony w klasie w związku ze swoją tuszą, która uniemożliwiała mu pełne uczestnictwo w zajęciach wychowania fizycznego. Brak określonych umiejętności, związanych z siłą i tężyzną fizyczną, w oczach innych chłopców odbierany był jako coś niemęskiego.

Czy męskość się kojarzy ze sprawnością fizyczną? Może się kojarzyć, tak mi się wydaje, że ludziom się kojarzy. No więc ja kiedyś byłem gruby, bardzo gruby, miałem taki brzuch, policzki, i tak dalej i na WF-ie, z racji ograniczeń fizycznych, pewne rzeczy mi nie wychodziły. I wtedy ludzie się śmiali. Od tamtej pory robiłem co mogłem, żeby nie ćwiczyć na WF-ie. Jeśli byłem odrzucany, to nie z racji swojego homoseksualizmu tylko w ramach jakiegoś określonego kontekstu - lekcji WF-u. Tam mogłem poczuć poniżenie w jakimś tam stopniu. Starałem się trzymać od nich jak najdalej. Nie wychodzi mi, więc nie będę tego robił po prostu. Nie miałem jakiejś takiej motywacji, by wszystkim pokazać, że jednak potrafię stać na tych rękach (Paweł, 27).

Jak piszą Barron i Bradford: „niewłaściwe - nieusportowione - ciała, są łatwo marginalizowane i wykluczane" (Barron, Bradford 2007, s. 249).

Na koniec chciałbym przytoczyć fragment wypowiedzi Irka, który opowiedział mi o trudnościach związanych z niezrozumieniem zasad "gry w męskość". Mężczyzna długo uczył się binarnego układu płciowego i tego, co oczekuje od niego społeczeństwo. Jego słowa obnażają konstrukcyjny, kulturowy charakter tożsamości płciowej. Jej oczywistość, jak się okazuje, nie jest zrozumiała dla wszystkich tylko przez fakt urodzenia się kobietą lub mężczyzną. Respondent skarżył się na nieposiadanie przewodnika w "męskim świecie” (ojciec tej funkcji nie spełnił), i że do rozumienia (tradycyjnej) męskości musiał dochodzić długo sam. Ostatecznie jego biografia, przynajmniej w narracji, którą się ze mną podzielił, wydaje się świadczyć o defeminizacji swych wczesnodziecięcych zachowań i akceptacji normatywnej męskości (czegoś, co kiedyś było dla niego niedostępne, niezrozumiałe, choć jej atrakcyjność wcześnie została uznana).

Ja w sumie taki swój model męskości musiałem wypracować dużo później. Bo ja byłem taki poza. Ja zresztą przez cały czas i to już w podstawówce miałem takie wrażenie, że jak mnie pytali: „,a co ty się tak zachowujesz? Jesteś, chłopak, czy dziewczyna?” Ja mówię, ,jestem Irek". Ja zawsze miałem takie poczucie, że jestem ponad tymi podziałami. Że ktoś się musi zachowywać tak, bo jest chłopak, że ktoś się musi zachowywać tak, bo jest dziewczyną. Jestem Ja i tyle. Jestem sobą! To dopiero po jakimś czasie, nie wiem, być może ze względu na coraz silniejszą socjalizację. Ja jednak po prostu zbudowałem 
swoje pojęcie, co to znaczy mężczyzna i tyle. Nie żeby jakoś... Bo mi tego brakowało. Rzeczywiście, jak ja się nad tym potem zastanawiałem, to stwierdziłem, że nie bardzo wiem o co chodzi. Dlaczego oni są tacy, a ja nie wiem o co im chodzi? (Irek, 45).

\section{Przekraczanie norm płci we wczesnej młodości i tego konsekwencje}

Wyjście poza przypisaną dla danej płci rolę jest kulturowym i społecznym skandalem, który w oczach normatywnej większości zasługuje na odpowiednią sankcję. Reprymenda rodziny i rówieśników ma charakter pedagogiczny. Służy zwróceniu uwagi na te zachowania jednostki, które nie mieszczą się w stereotypie "normalnego chłopca". Krytyka płciowego nonkonformizmu jest rytuałem, który musi się stale odbywać. Odpowiednie słowa, gesty, spojrzenia lub czyny muszą zostać użyte w takiej sytuacji, aby zaznaczyć nadzwyczajność, spektakularność tego nienormalnego zachowania. Przykłady nienormatywnych płciowo zachowań, które mogą spotkać się z negatywną reakcją otoczenia, zostały już podane powyżej. W tym miejscu można je uzupełnić o „niechłopięce" hobby/zainteresowania, jak taniec na przykład, lub niekonwencjonalne formy spędzania czasu wolnego.

Ja nie grałem na przykład w piłkę nigdy. Ten sport mnie nigdy nie pociągał. Natomiast parę razy, może nawet więcej, zdarzyło mi się zagrać z dziewczynami w gumę, co było jakby dodatkowym pretekstem, żeby mi ...dowalić. (...) Pamiętam tylko, że moja wu-efistka się martwiła i powiedziała przy dziewczynach, żeby nie grały ze mną, żeby nie namawiały mnie żebym grał z nimi w gumę. One mi to powiedziały (Robert, 29).

(...) lubiłem grać w kabel [skakać przez sznur - BL], w co też przede wszystkim bawiły się dziewczyny. To też zawsze wiązało się z jakąśs reakcją otoczenia. Pamiętam, że były dwie takie dziewczyny - siostry, i ich rodzice kilka razy puścili jakiś komentarz w moją stronę, "czy ja czasem nie powinienem kopać piłki?" (Michał, 23).

"Troska" o "genderową higienę" dzieci, jak pokazują dwa powyższe cytaty, wydaje się być generalnym obowiązkiem, powinnością starszych lub bardziej kompetentnych osób, również postronnych. Jak się okazuje, nawet zwykłe dziecięce zabawy mają płeć, a zaangażowanie $w$ nie "niewłaściwych graczy” może rzutować na ich późniejszą tożsamość (w tym, jak się można domyślać, seksualną).

W reakcji na przekroczenie norm płci najczęstszym narzędziem, po które sięga się, by oddać "niezwykłość” takiego działania, jest śmiech (por. Lis 2007, s. 265-268). Bywa, że jest on tylko komunikatem dla małoletniego i dla innych obserwatorów wydarzenia, iż mamy świadomość, że to co się dzieje, nie jest "na poważnie". Jest kabaretem, zabawą, chwilą nieugładzonego, teatralnego karnawału. Chłopczyk ubierający sukienkę swojej mamy, malujący niezdarnie pomadką swe małe usta, jest elementem przedstawienia dla dorosłych. Śmiech, który go spotyka, nie jest szyderczy, krzywdzący, choć trudno odmówić mu również ukrytych funkcji socjalizacyjnych. 
Jako dziecko to się przebieraliśmy, dosyć częste zabawy. Ubrać się w stroje mamy, pomalować, zwłaszcza nie trafiając w usta, jak się ma 5 lat, to było dla dorosłych śmieszne (Adam, 19).

Funkcje (nie)werbalnego regulowania przestrzeni dopuszczalnych zachowań mogą być różne. Korekcja - wymazanie złych, niedobrych nawyków; kara - symboliczne zadośćuczynienie chaosowi, który wdarł się w uporządkowaną przestrzeń społeczną za sprawą „,błędnego" odczytania męskiej/kobiecej roli; prewencja - pokazanie innym, że nienormatywność nie może liczyć na nagrodę, a również pokazanie swoją „policyjną" postawą, że mieścimy się w mainstreamie zachowań, „nauczyliśmy się naszej roli na tyle dobrze, że sami możemy być dla innych drogowskazem". Przy czym, niech to będzie wyraźnie zaznaczone, zwykle brakuje świadomości, że "genderowe kompetencje", które te osoby posiadają, zostały opanowane w wyniku socjalizacji i nie są niczym oczywistym/naturalnym.

„Klucz”, według którego opresorzy (,edukatorzy”?) czytają nienormatywność rówieśników, jest dość rozbudowany. To nie tylko jawnie "dziewczęce"/"antychłopięce" zachowanie, ale również kwestia choroby, otyłości czy nawet bardzo dobrych wyników w nauce bywa pretekstem do odebrania męskości ofierze. Przykłady płciowej nienormatywności, jakkolwiek rozumianej, mogą dotyczyć tak samo biografii mężczyzn homoseksualnych, jak i wielu heteroseksualistów. Taywaditep pisze, że nienormatywni genderowo chłopcy stopniowo defeminizują swoje zachowania, tak że w dorosłym życiu pozostają ich nieliczne ślady. Jest to spowodowane presją otoczenia i waloryzowaniem $w$ kulturze zachowań uznawanych za "męskie”. Lęk przed byciem wyśmianym, pobitym albo wykluczonym z grupowych aktywności bywa wystarczającym regulatorem płciowych zachowań chłopców (Taywaditep 2002, s. 6). Choć w wywiadach odnotowałem również liczne opowieści o tradycyjnym, konformistycznym dzieciństwie, które są dowodem udanej socjalizacji płciowej, to jednak w tym miejscu skupiłem się głównie na tych narracjach, które pozwalają nam dostrzec normatywizujące procedury i ich skutki.

\section{Literatura:}

Barron M., Bradford S., 2007, Corporeal Controls. Violence, Bodies, and Young Gay Men's Identity, "Youth \& Society”, Vol. 39, No. 2.

Epstein D., 2006, Real Boys don't work. "Underachievement", masculinity and the harassment of "sissies" [w:] S. M. Whitehead (red.), Men and Masculinities: Critical Concepts in Sociology (vol. II), Routledge, London/New York.

Fee D., 2000, "One of the Guys”. Instrumentality and Intimacy in Gay Men's Friendships with Straight Men [w:] P. Nardi (red.), Gay Masculinities, SAGE Publications, Thousand OaksLondon-New Delhi.

Levine M.P., 1998, The Life and Death of Gay Clones [w:] M.S. Kimmel, M.A. Messner (red.), Men's Lives, Allyn and Bacon, Boston-London. 
Lis B., 2007, Śmiech jako narzędzie normalizacji oraz strategia oporu. Rzecz o subwersywności komizmu w Little Britain [w:] M. Baer, M. Lizurej (red.), Z odmiennej perspektywy. Studia queer $w$ Polsce, Oficyna Wydawnicza Arboretum, Wrocław.

Li B., 2010, Męskość i władza. Refleksja nad receptywnościq i praktykami S/M w seksie między mężczyznami [w:] E. Banaszak, P. Czajkowski (red.), Corpus delicti-rozkoszne ciało. Szkice nie tylko z socjologii ciała, Difin, Warszawa.

Padva G., 2002, Heavenly Monsters: The Politics of the Male Body In the Naked Issue of Attitude Magazine, „International Journal of Sexuality and Gender Studies”, Vol. 4, No. 7.

Pascoe C.J., 2005, Dude You're a Fag: Adolescent Masculinity and the Fag Discourse, "Sexualities”, Vol. 8, No. 3.

Pascoe C.J., 2007, Dude You're a Fag. Masculinity and Sexuality in High School, University of California Press, Berkley.

Redman P., 2000, "Tarred with the Same Brush": "Homophobia" and the Role of the Unconscious in School-based Cultures of Masculinity, "Sexualities", Vol. 3, No. 4.

Renold E., 2002, Presumed innocence. (Hetero)sexual, heterosexist and homophobic harassment among primary school girls and boys, "Childhood", Vol. 9, No. 4.

Taywaditep K.J., 2002, Marginalization Among the Marginalized, "Journal of Homosexuality", Vol. 42, No. 1.

\section{Summary}

Socialization to the normative masculinity: institutions and mechanisms shaping heterohabitus. Examples

This article is an exploration of mechanisms that relate to constructions of dominant straight masculinity. The collected narratives reveal the regulative role of violence, and reveal the interplaying dynamics of community, family, peers and schools, the boys are involved in constant negotiation over multiple and intersecting identities.

Keywords

masculinities, socialization, heteronormativity, habitus, oppression, childhood

\section{Słowa kluczowe}

męskości, socjalizacja, heteronormatywność, habitus, opresja, dzieciństwo 
